Artikel Penelitian

\title{
Gambaran Asupan Folat Mahasiswa Fakultas Kedokteran Universitas Andalas
}

Fido Arif ${ }^{1}$, Fadil Oenzil $^{2}$, Yenita $^{3}$

\section{Abstrak}

Salah satu defisiensi mikronutrien yang masih dihadapi Indonesia adalah defisiensi folat. Jumlah rata-rata asupan folat yang harus dikonsumsi oleh dewasa muda yang berumur 17-29 tahun berdasarkan Angka Kecukupan Gizi (AKG) yaitu $400 \mu \mathrm{g} / \mathrm{hari}$. Tujuan penelitian ini adalah mengetahui jumlah asupan folat/hari individu. Penelitian ini merupakan penelitian survai deskriptif yang menggunakan metode food recall 24 jam. Responden dari penelitian ini adalah mahasiswa Fakultas Kedokteran Universitas Andalas (FK Unand). Digunakan metode sistematik sampling untuk mendapatkan 273 orang responden. Responden diwawancara oleh enumerator dengan bantuan food model, setelah itu digunakan program Nutri Survey 2007 untuk mendapatkan jumlah asupan folat responden. Hasil penelitian menunjukkan bahwa sebagian besar $(96,8 \%)$ mahasiswa FK Unand memiliki asupan folat sehari yang kurang, dengan rata-rata $111 \pm 119 \mu \mathrm{g} / \mathrm{hari}$. Hasil analisis data didapatkan bahwa rata-rata responden laki-laki lebih banyak $(129 \pm 48$ $\mu \mathrm{g} / \mathrm{hari})$ mengonsumsi folat dari pada responden perempuan $(98 \pm 88 \mu \mathrm{g} / \mathrm{hari})$, juga didapatkan data bahwa rata-rata responden yang tinggal dengan orang tua atau wali lebih banyak mengonsumsi folat $(130 \pm 155 \mu \mathrm{g} / \mathrm{hari})$ dari pada responden yang tinggal sendiri di kost atau kontrakan $(101 \pm 91 \mu \mathrm{g} / \mathrm{hari})$. Simpulan penelitian ini adalah lebih dari $90 \%$ mahasiswa FK Unand tidak mengonsumsi folat yang cukup. Rata-rata asupan folat/hari laki-laki lebih tinggi 1,3 kali dari pada perempuan.

Kata Kunci: AKG, food recall 24 jam, folat

\section{Abstract}

One of micronutrients deficiency in Indonesia is folate deficiency. Folate has to consume by adult 17-29 years old based on Recommended Daily Intake (RDI) is $400 \mu \mathrm{g} /$ day. The objective of this study was to know an individual consume of folate/day. This was descriptive study that using a 24-hour food recall method. Respondents of this study were students in Faculty Of Medicine University of Andalas (FK Unand). Systematic sampling method is used to get 273 the respondents. Respondents were interviewed by enumerator with food model and to get an amount of folate intake that used Nutri Survey 2007's program. The result show that the most of (96,8\%) medical students of Andalas University had less folate intake by an average of $111 \pm 119 \mu \mathrm{g} /$ day. Analysis of the data show that an average male

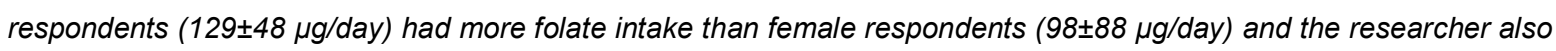
found that respondents who lived with parents or gurdians consumes more folate $(130 \pm 155 \mu \mathrm{g} /$ day $)$ than respondents who lived alone in the boarding or rented house $(101 \pm 91 \mu \mathrm{g} /$ day). The conclusion of this study is more than $90 \%$ of the medical students of Andalas University do not fulfill minimum intake of folate needed by body based on (RDI). An average intake of folate/day in men is higher 1.3 times than women.

Keywords: RDI, food recall 24 hours, folate

Affiliasi penulis: 1. Prodi Profesi Dokter FK Unand (Fakultas Kedokteran Universitas Andalas Padang), 2. Bagian Biokimia FK Unand, 3.Bagian Patologi Anatomi FK Unand

Korespondensi :Fido Arif, fidoarief@yahoo.com, Telp: 081277898852

\begin{abstract}
PENDAHULUAN
Mikronutrien merupakan nutrisi yang dibutuhkan oleh manusia dalam jumlah kecil, yang terdiri dari mineral dan vitamin. ${ }^{1}$ Mineral mencangkup
\end{abstract}


natrium, kalium, besi, kobalt, kromium, dan lain-lain. Sedangkan vitamin terbagi menjadi vitamin yang larut lemak terdiri dari vitamin $A, D, E$ dan $K$ serta vitamin yang larut dalam air yaitu vitamin $\mathrm{B}$ dan $\mathrm{C}^{2}$

Menurut World Health Organization (WHO) pada tahun 2007 lebih dari dua miliar penduduk dunia diperkirakan mengalami defisiensi mineral dan vitamin yang penting bagi tubuh. Kekurangan mikronutrien dianggap sebagai masalah kesehatan global yang harus diwaspadai. ${ }^{3}$

Salah satu defisiensi mikronutrien yang masih terjadi didunia adalah masalah defisiensi folat. Berdasarkan data survai dari beberapa negara yang yang dilakukan oleh WHO, defisiensi vitamin B-12 dan folat akan menjadi masalah kesehatan masyarakat yang bisa mempengaruhi jutaan orang di seluruh dunia. $^{4}$

Pentingnya peranan folat membuat tubuh tidak boleh mengalami defisiensi folat. Salah satu peran folat adalah sebagai ko-enzim dalam proses sintesis Deoxyribo Nucleic Acid (DNA). Defisiensi zat tersebut akan menyebabkan gangguan dalam sintesis DNA pada sel, dimana pembelahan kromosom sedang terjadi. Sistem hematopoiesis merupakan salah satu sistem organ yang akan terkena dampak dari terganggunya proses sintesis DNA. ${ }^{5}$ Sebuah penelitian yang dilakukan oleh George pada tahun 2005,membuktikan pentingnya peranan folat dalam kehidupan manusia. Hasilnya menunjukkan bahwa orang-orang yang mengonsumsi asam folat $0,2 \mathrm{mg}$ selama rata-rata 8 bulan, mengalami penurunan kadar homosistein darah hingga sebesar $13 \%$. Sedangkan mereka yang mengonsumsi asam folat $5 \mathrm{mg}$ mengalami penurunan homosistein darah hingga $25 \%{ }^{6}$

Amerika, Australia, serta beberapa tempat lainnya melakukan penelitian terhadap kecukupan asupan folat individu. Di Indonesia sendiri penelitian tentang asupan folat masih belum popular.

Berdasarkan penelitian yang dilakukan oleh Khotimah pada tahun 2013, tentang gambaran asupan makanan pada beberapa mahasiswa FK Unand, peneliti mendapatkan data bahwa mahasiswa FK Unand kurang mengonsumsi sayur dan buah sedangkan sayur dan buah merupakan sumber utama folat, sehingga perlu dilakukan penelitian tentang gambaran asupan folat pada mahasiswa Fakultas Kedokteran Universitas Andalas. ${ }^{7}$

Pengukuran asupan folat ini dapat dilakukan dengan berbagai metode pengukuran. Metode yang sering digunakan adalah metode food recall 24 jam. Metode food recall 24 jam sering digunakan karena memiliki beberapa kelebihan yaitu sederhana, tidak terlalu membebani responden, serta relatif murah. ${ }^{8}$ Metode ini juga memiliki kekurangan seperti validitasnya tergantung pada daya ingat responden. ${ }^{9}$

\section{METODE}

Penelitian ini menggunakan metode Food Recall 24 jam. Wawancara dilakukan oleh enumerator dengan bantuan food model. Responden adalah mahasiswa pendidikan dokter FK Unand.Pengambilan responden menggunakan teknik systematic sampling.

HASIL

Berdasarkan penelitian yang telah dilaksanakan, diperoleh informasi mengenai gambaran karakteristik subyek penelitian seperti Tabel 1 berikut.

Tabel 1. Karakteristik umum responden

\begin{tabular}{lcc}
\hline Variabel & Jumlah & $\mathbf{( \% )}$ \\
\hline $\begin{array}{l}\text { Umur } \\
17-24 \text { tahun }\end{array}$ & 273 & 100 \\
\hline Total & 273 & 100 \\
\hline Jenis Kelamin & & \\
Laki-laki & 118 & 43,23 \\
Perempuan & 155 & 56,77 \\
\hline Total & 273 & 100 \\
\hline Tinggal Di Padang & 175 & 63,11 \\
Kost/kontrakan & 98 & 35,89 \\
Dengan orang tua/wali & 273 & 100 \\
\hline Total & & \\
\hline
\end{tabular}

Berdasarkan Tabel 1, dapat dilihat bahwa $56,77 \%$ responden adalah perempuan, sedangkan laki-laki 43,23\%. Responden yang tinggal dengan orang tua atau wali berjumlah $35,89 \%$, dan yang tinggal sendiri di kost atau kontrakan $63,11 \%$.

\section{Gambaran Asupan Folat Mahasiswa Secara Umum}

Hasil analisis univariat menggambarkan distribusi asupan folat pada mahasiswa Fakultas 
Kedokteran Universitas Andalas secara umum sebagai berikut.

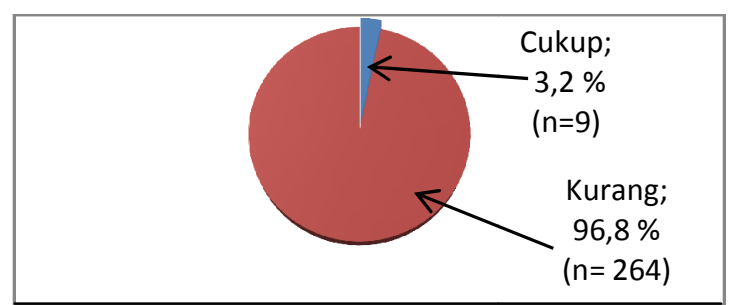

Gambar 1. Diagram distribusi responden berdasarkan asupan folat

\section{Gambaran Asupan Folat Berdasarkan Jenis}

\section{Kelamin}

Dalam penelitian ini terdapat 118 laki-laki yang dilakukan wawancara, serta 155 perempuan.Laki-laki yang mengonsumsi cukup folat hanya 8 orang, sedangkan wanita hanya 3 orang. Gambaran asupan folat berdasarkan jenis kelamin dapat dilihat pada tabel 2 berikut:

Tabel 2. Gambaran asupan folat responden berdasarkan jenis kelamin

\begin{tabular}{lcc}
\hline \multicolumn{1}{c}{ Jenis Kelamin } & $\mathbf{n}$ & $\begin{array}{c}\text { Rerata } \pm \text { SD } \\
(\boldsymbol{\mu g} / \mathbf{h a r i})\end{array}$ \\
\hline Laki-Laki & 118 & $129 \pm 48$ \\
Cukup asupan folat & 8 & $532 \pm 317$ \\
Kurang asupan folat & 110 & $100 \pm 66$ \\
Perempuan & 155 & $98 \pm 88$ \\
& & \\
Cukup asupan folat & 3 & $570 \pm 187$ \\
Kurang asupan folat & 152 & $88 \pm 54$ \\
\end{tabular}

Pada Tabel 2 dapat disimpulkan bahwa rerata responden laki-laki lebih banyak $(129 \pm 48 \mu \mathrm{g} / \mathrm{hari})$ mengonsumsi folat daripada responden perempuan $(98 \pm 88 \mu \mathrm{g} / \mathrm{hari})$.

\section{Gambaran Asupan Folat Berdasarkan Tempat Tinggal}

Dalam penelitian ini terdapat 98 responden tinggal dengan orang tua dan wali yang dilakukan wawancara, serta 175 responden tinggal sendiri di kost atau kontrakan. Gambaran asupan folat berdasarkan tempat tinggal dapat dilihat pada Tabel 3 berikut:

Tabel 3. Gambaran asupan folat responden menurut tempat tinggal

\begin{tabular}{lcc}
\hline & $\mathbf{n}$ & $\begin{array}{c}\text { Rerata } \pm \text { SD } \\
(\boldsymbol{\mu g} / \mathrm{hari})\end{array}$ \\
\hline Dengan orang tua atau wali & 98 & $130 \pm 155$ \\
$\begin{array}{lcc}\text { Cukup asupan folat } \\
\text { Kurang asupan folat }\end{array}$ & 62 & $600 \pm 344$ \\
& & $100 \pm 60$ \\
Kost atau kontrakan & 175 & $101 \pm 91$ \\
$\begin{array}{l}\text { Cukup asupan folat } \\
\text { Kurang asupan folat }\end{array}$ & 5 & $473 \pm 187$ \\
& 170 & $90 \pm 59$
\end{tabular}

Dari Tabel 3 dapat disimpulkan bahwa rerata asupan folat responden yang tinggal dengan orang tua atau wali lebih tinggi $(130 \pm 155 \mu \mathrm{g} / \mathrm{hari})$ daripada responden yang tinggal sendiri di kost atau kontrakan (101 $\pm 91 \mu \mathrm{g} / \mathrm{hari})$.

\section{PEMBAHASAN}

Hasil studi ini mendapatkan 96,8\% ( $n=264)$ responden kurang mengonsumsi folat $(<80 \%$ dari 400 $\mu \mathrm{g} /$ hari berdasarkan AKG) dalam makanan sehari-hari, hanya $3,2 \% \quad(n=9)$ responden yang cukup mengonsumsi folat $(\geq 80 \%$ dari $400 \mu \mathrm{g} / \mathrm{hari}$ berdasarkan AKG). Kurangnya asupan folat dapat disebabkan oleh kurangnya asupan makanan yang mengandung folat, serta pengetahuan yang kurang tentang pentingnya peranan folat dalam kehidupan.

Penelitian lain tentang asupan folat pernah dilakukan pada ibu hamil di Kabupaten Gowa, Makassar oleh Devianty et al. Metode yang digunakan adalah semi quantitative food frequency questionnaire (SQ-FFQ), dari penelitian tersebut didapatkan hasil bahwa 97,8\% ibu hamil di Kabupaten Gowa memilki asupan folat yang kurang, hanya 2,2 \% dari ibu hamil tersebut yang cukup mengkonsumsi folat dalam makanan sehari-harinya. ${ }^{10}$ Bailey et al pada tahun 2010, juga melakukan penelitian di Amerika tentang asupan folat pada masyarakat Amerika, hasilnya menunjukkan bahwa rerata asupan folat laki-laki di 
Amerika adalah $813 \pm 14 \mu \mathrm{g} / \mathrm{hari}$, sedangkan untuk wanita adalah $724 \pm 16 \mu \mathrm{g} /$ hari. $^{11}$ Koksal et al dalam penelitiannya terhadap anak sekolah di sebuah provinsi di negara Turki dengan umur antara7-11 tahun melaporkan bahwa 9,3\% respondennya memilki asupan folat yang tidak adekuat. ${ }^{12}$ Salah satu hal yang dapat mempengaruhi asupan folat ini adalah pola makan yang tidak sehat seperti mengonsumsi makanan olahan. Arisman pada tahun 2007, menyampaikan bahwa salah satu masalah serius yang dihadapi dunia sekarang adalah konsumsi makanan olahan, seperti yang ditayangkan dalam iklan televisi secara berlebihan. Makanan ini, meski dalam iklan diklaim kaya akan vitamin dan mineral, seringkali makanan tersebut banyak mengandung gula serta lemak, disamping zat adiktif. ${ }^{13}$

Perbandingan antara penelitian Devianty et al dengan hasil penelitian ini menunjukkan hal yang hampir sama, yaitu asupan folat masyarakat masih rendah, tetapi dua penelitian ini memilki perbedaan dalam hal responden dan metode yang digunakan untuk melihat asupan folat.Asupan folat pada mahasiswa FK Unand masih rendah dapat disebabkan karena tingkat pengetahuan tentang pentingnya folat yang masih rendah atau karena ketidaktahuan tentang sumber-sumber makanan yang mengandung folat. Hal lain yang juga dapat mempengaruhi adalah kebiasaan mengonsumsi makanan cepat saji. ${ }^{10}$

Dari hasil penelitian ini didapatkan data bahwa rata-rata asupan folat pada laki-laki yang berusia 17-24 tahun $(129 \pm 48 \mu \mathrm{g} /$ hari) 1,3 kali lebih tinggi jika dibandingkan dengan asupan folat perempuan yang berusia sama $(98 \pm 88 \mu \mathrm{g} / \mathrm{hari})$. Hal ini sama dengan hasil penelitian yang dilakukan oleh Koksal et al pada tahun 2011 di Turki, bahwa asupan folat pada laki-laki yang berusia 12-16 tahun lebih tinggi $(269.5 \pm 12.4 \mu \mathrm{g} / \mathrm{hari})$ daripada asupan folat perempuan yang berusia sama $(261.0 \pm 10.06$ $\mu \mathrm{g} / \mathrm{hari}) .{ }^{12}$ Hasil yang didapatkan oleh Bailey et al dalam penelitiannya juga menunjukkan hal yang sama bahwa asupan folat pada laki-laki yang berusia 19-30 tahun lebih tinggi $(774 \pm 28 \mu \mathrm{g} / \mathrm{hari})$ dari pada perempuan $\left(645 \pm 17 \mu \mathrm{g} /\right.$ hari). ${ }^{11}$ Hal ini mungkin disebabkan oleh pola diet sehari-hari yang berbeda antara laki-laki dan perempuan. Laki-laki cenderung lebih banyak mengonsumsi makanan, sedangkan perempuan lebih sedikit karena takutnya wanita akan obesitas dan penambahan berat badan. Sebuah penelitian menyebutkan bahwa remaja putri malah melewatkan dua kali waktu makan dan lebih memilih kudapan. Sebagian besar kudapan bukan hanya hampa kalori, tetapi juga sedikit sekali mengandung zat gizi, selain dapat mengganggu nafsu makan. ${ }^{13}$

Hasil lain yang didapatkan dalam penelitian ini adalah, responden yang tinggal dengan orang tua atau wali memilki rata-rata asupan folat $(130 \pm 155 \mu \mathrm{g} /$ hari) 1,3 kali lebih tinggi jika dibandingkan dengan responden yang tinggal sendiri di kost atau kontrakan (101 $\pm 91 \mu \mathrm{g} / \mathrm{hari})$. Hal ini dapat disebabkan oleh asupan makanan yang berbeda antara responden yang tinggal sendiri dan responden yang tinggal dengan orang tua atau wali. Responden yang tinggal sendiri lebih cenderung memilih makanan cepat saji dan tidak mengonsumsi buah serta sayur. Faktor lain yang juga mempengaruhi adalah pengaruh dari teman sebaya, yang dapat menyebabkan perubahan signifikan dalam kebiasaan makan. ${ }^{14}$ Jika pola makan seseorang salah, dapat mempengaruhi pola makan teman sebayanya sendiri.

\section{SIMPULAN}

Lebih dari 90\% mahasiswa FK Unand tidak mengonsumsi folat yang cukup. Rata-rata asupan folat laki-laki lebih tinggi 1,3 kali daripada asupan folat perempuan. Rata-rata asupan folat mahasiswa yang tinggal dengan orang tua atau wali lebih tinggi 1,3 kali daripada asupan folat mahasiswa yang tinggal sendiri di kost atau di kontrakan.

\section{DAFTAR PUSTAKA}

1. Newman D. Kamus kedokteran Dorland. Jakarta: EGC; 2010.hlm.1351.

2. Bender D, Peter AM. Micronutrients: vitamin and minerals. Dalam:Robert K, Daryl K., Victor W, editor (penyunting). Harper's Illustrated Biochemistry. Edisi ke-26. Amerika Serikat: The McGraw-Hill Companies;2003.hlm.481-98.

3. World Health Organization (WHO). Preventing and controlling micronutrient deficiencies in populations affected by an emergency. 2007 (diunduh 12 Mei 2013). Tersedia dari: URL: HYPERLINK 
http://www.who.int/nutrition/publications/WHO WF

\section{P UNICEFStatement.pdf}

4. Benoist DB. Conclusions of a WHO technical consultation on folate and vitamin B-12 deficiensies. 2008 (diunduh 12 Mei 2013). Tersedia dari: URL: HYPERLINK http://www.who.int/ nutrition/publications/micronutrients/WHO WFP U NICEFstatement.pdf

5. Soenarto. Anemia megaloblastik. Dalam: Aru W, Setiyohadi, Alwi, Simadibrata, Setiati, editor (penyunting). Buku Ajar IImu Penyakit Dalam Jilid II. Edisi ke-5. Jakarta: Interna Publishing; 2009.hlm.1141-51.

6. George. The Controversial role B-vitamins in cardiovascular risk: An Update. Archives of Cardiovascular Disease. 2009;102:847-54.

7. Khotimah $\mathrm{H}$. Faktor yang mempengaruhi kejadian overweight dan obesitas pada mahasiswa Fakultas Kedokteran Universitas Andalas angkatan 2010, 2011, dan 2012 (skripsi). Padang: Fakultas Kedokteran Universitas Andalas; 2013.

8. Arsana. Perbedaan rata-rata intake energi, protein, lemak, karbohidrat menggunakan metode recall 24 jam dengan food record sebagai gold standar pada pasien diabetes mellitus di RSUD Saiful Anwar Malang (Laporan Penelitian). Malang: Fakultas IImu Gizi Brawijaya; 2010.

9. Nyoman DS, Bakhri B, Ibnu F. Penilaian status gizi. Jakarta: EGC; 2001.hlm.113-4.

10. Devianty C., Indriasari R., Salam A. Gambaran pola konsumsi asam folat dan status asam folat pada ibu hamil di Kabupaten Gowa. Jurnal Program Studi FKM Universitas Hassanuddin, Makasar. 2013.

11. Bailey BL, Susan M, Jesse F GIII. Folate. Dalam: Barbara A. Bowman, Robert M. Russel, editor (penyunting). Present knowledge in nutrition. Edisi ke-8. Amerika Serikat: ILSI; 2001.hlm.214-29.

12. Koksal E, Ayaz A, Kucukerdonmez O. Nutritional status in school children: Deficiencies in iron, folic acid and Vitamin B-12. Academic Journals, Scientific Reseacrh and Essays. 2011;6:21.

13. Arisman MB. Buku ajar ilmu gizi: Gizi dalam daur kehidupan. Jakarta: EGC; 2008.

14. Barasi ME. At a glance: ilmu gizi. Jakarta: Erlangga; 2007. 